\title{
LAND SNAIL FAUNA OF “PORTILE DE FIER” (“IRON GATES”) NATURE PARK (BANAT, ROMANIA)
}

Voichiţa GHEOCA *

* "Lucian Blaga“ University of Sibiu, Faculty of Sciences, Department of Ecology and Environment Protection, Dr. Ioan Rațiu Street 5-7, Sibiu, Sibiu County, Romania, RO-550012, vgheoca@yahoo.com

KEYWORDS: land snails, limestone, karst, “Iron Gates”, Romania.

\section{ABSTRACT}

The paper presents an analysis of terrestrial mollusc fauna of the "Iron Gates" Nature Park. Various types of habitats (e.g. forests, rocks, riparian areas) and substrates (e.g. limestone, conglomerate, crystalline schist) were analyzed. A total of 45 species of terrestrial gastropods were identified in 17 sampling points, four of which are mentioned for the first time in the area. Six other species cited in the literature were not found. Limestone substrate allows the development of large populations of terrestrial gastropods, but the specific diversity is larger when it is associated with a forest habitat. The current legal and illegal exploitation of limestone threatens the mollusc communities associated with this type of habitat. The subsequent erosion process and the low mobility of these animals make their colonization of habitats difficult.

RÉSUMÉ: Note sur la faune des gastéropodes terrestres du Park Naturel "Portes de Fer" ("Porțile de Fier").

Ce travail présente une analyse de la faune des mollusques terrestres du Park Naturel "Portes de Fer". Différents types d'habitats (forêts, rochers, des zones riveraines) et de substrats (schistes calcaires, conglomérats, cristallins) ont été analysées. Un total de 45 espèces de gastéropodes terrestres ont été identifiées dans les 17 points de prélèvement, dont quatre sont mentionnées pour la première fois dans la région. Six autres espèces citées dans la littérature n’ont été pas retrouvées. Le substrat calcaire permet le développement d'importantes populations de gastéropodes terrestres, mais la diversité spécifique est supérieure quand celuici est associé à un habitat forestier. L'exploitation légale et illégale de matériaux de construction met en danger les communautés de mollusques terrestres associées à ce type d'habitat. De plus, la recolonisation est difficile à cause de l'érosion déclenchée après la fin des opérations et à la faible mobilité de ces animaux.

REZUMAT: Note asupra faunei de gastropode terestre din Parcul Natural „Porțile de Fier”.

Lucrarea prezintă o analiză a faunei de moluște terestre din Parcul Natural „Porțile de Fier”. Diverse tipuri de habitate (păduri, stâncării, zone ripariene) și de substrate (calcar, conglomerate, şisturi cristaline). Un număr de 45 specii de gastropode terestre au fost identificate în cele 17 puncte de colectare, patru dintre acestea fiind menționate pentru prima oară în regiune. Alte șase specii citate în literatură nu au fost regăsite. Substratul calcaros permite dezvoltarea unor populații impresionante de gastropode terestre, diversitatea specifică fiind mai mare atunci când acesta este asociat cu un habitat forestier. Exploatarea materialelor de construcții prin dezvoltarea carierelor legale și ilegale, periclitează comunitățile de moluște terestre asociate cu acest tip de habitat, iar procesele de eroziune declanșate după încetarea exploatării, precum și mobilitatea redusă a acestor animale fac dificilă recolonizarea. 


\section{INTRODUCTION}

The "Iron Gates" Nature Park is one of the most represented areas within the karstic relief of Romania. The substrate of crystalline schists is covered by Cretaceous limestone (e.g. Sirinia, Sviniţa, "Iron Gates") and conglomerates on the line Sviniţa - Svinecea and sandstones, shales in the Sicheviţa in Danube Gorge (*, 1987; **, 1992). The warm climate of the region, enhanced by the presence of limestone, determines the prevalence of Balkanic, Mediterranean and sub-Mediterranean plant species (Pătroescu et al., 2007).

The karst areas are generally the source of large biodiversity due to the multitude of ecological niches generated by the complexity of the landscape and the variable climatic conditions. Also, high species endemism can occur on karsts (Culver et al., 2000). Among the outstanding groups populating these areas, are also those requiring large amounts of calcium like the snails. It is known that lime-rich habitats often support abundant and diverse land snail communities (Horsák, 2006; Nekola, 1999; Kerney and Cameron, 1979), due to their high metabolic calcium demands - not only for shell generation, but also for egg production (Gärdenfors, 1992). Snails contribute to the general biodiversity by developing large populations, therefore making them important contributors to the invertebrate biomass.

Previously, the land snail fauna from the concerned area was the object of several general or specific researches. The most comprehensive is the monograph of Romanian gastropods (Grossu, 1981, 1983, 1987), a valuable image of the country's gastropod fauna for the 20th century. Other papers were more focused, describing the cave mollusc fauna (Negrea, 1962, 1963, 1964, 1966). More recently, Cameron et al. (2013) presents an analysis of the snail fauna from Banat including the "Iron Gates" and Dvořák (2002), analyzing some caves in the area and listing 12 species found there.

This work is meant to contribute to the assessment of biodiversity in the "Iron Gates" Nature Park, for a future management plan.

\section{MATERIAL AND METHODS}

The present paper is based on qualitative sampling during the summer of 2014, at 17 sampling stations (Fig. 1, Tab. 1). Samples were taken inside the "Iron Gates" Nature Park from limestone, conglomerates, and crystalline schist substrate. Calcareous rocks or conglomerates, exposed or located in deciduous forests, vertical walls, or wet riversides, were equally sampled in the eastern and the western part of the park. The location of the sampling points is presented in figure 1 . Snails were collected by hand by three collectors during one hour in each sampling site, and additional leaf litter sample was taken. About $20 \mathrm{l}$. of leaf litter was sieved and the material was sorted and identified in the laboratory. Grossu (1981, 1983, 1986, 1987) and Welter-Schultes (2012) were used for species identification.

\section{RESULTS AND DISCUSSION}

A number of 45 land snail species were identified in the area, some of which are reported here for the first time. The other six species have been mentioned in previous works, raising the number of land snail species in the area to 51 .

The systematic list of encountered species is presented below. Since most of the previous works are confined to restricted areas, as is the case of the researches regarding the land snail fauna from caves, or are scattered reports of some species in taxonomic reviews, we will only consider two references: the comprehensive work of Grossu (Gastropoda Romaniae, 1983, 1985, 1986, 1987), and the recent research concerning the malacofauna from Banat (Cameron et al., 2013). 
Table 1: Location and description of sampling points.

\begin{tabular}{|c|l|l|}
\hline No. & \multicolumn{1}{|c|}{ Location/habitat type/substrate } & \multicolumn{1}{|c|}{ Coordinates } \\
\hline 1. & Mraconia Valley - crystalline rocks in forest & $44.659977 \mathrm{~N}, 22.267286 \mathrm{E}$ \\
\hline 2. & Mraconia Valley - forest on schist substrate & $44.651388 \mathrm{~N}, 22.272791 \mathrm{E}$ \\
\hline 3. & Mraconia Valley - limestone wall & $44.644716 \mathrm{~N}, 22.290091 \mathrm{E}$ \\
\hline 4. & Ciucaru Mic - limestone rocks on the plateau & $44.632530 \mathrm{~N}, 22.282391 \mathrm{E}$ \\
\hline 5. & Ciucaru Mic - limestone rocks in the forest & $44.638658 \mathrm{~N}, 22.284875 \mathrm{E}$ \\
\hline 6. & Ciucaru Mare - limestone bare rocks on the top & $44.605283 \mathrm{~N}, 22.264263 \mathrm{E}$ \\
\hline 7. & Ciucaru Mare - limestone rocks in the forest & $44.607397 \mathrm{~N}, 22.265233 \mathrm{E}$ \\
\hline 8. & Plavişeviţa - forest on crystalline substrate & $44.543872 \mathrm{~N}, 22.210364 \mathrm{E}$ \\
\hline 9. & Sirinia Valley - limestone rocks in the forest & $44.6498583 \mathrm{~N}, 22.066794 \mathrm{E}$ \\
\hline 10. & Sirinia Valley - limestone wall & $44.6433056 \mathrm{~N}, 22.0563472 \mathrm{E}$ \\
\hline 11. & Sirinia Valley - wet side valley in forest with limestone & $44.638688 \mathrm{~N}, 22.05275 \mathrm{E}$ \\
\hline 12. & Drencova - open valley in forest & $44.632794 \mathrm{~N}, 22.008113 \mathrm{E}$ \\
\hline 13. & Liubotina - open valley near forest on crystalline substrate & $44.553141 \mathrm{~N}, 22.218083 \mathrm{E}$ \\
\hline 14. & Liborajdea - open valley near forest on crystalline substrate & $44.671582 \mathrm{~N}, 21.775245 \mathrm{E}$ \\
\hline 15. & Limestone rocks four km downstream Coronini & $44.655069 \mathrm{~N}, 21.723382 \mathrm{E}$ \\
\hline 16. & Limestone rocks near Gaura cu Muscă Cave & $44.664647 \mathrm{~N}, 21.699533 \mathrm{E}$ \\
\hline 17. & Limestone rocks in forest on a humid valley near Coronini & $44.668841 \mathrm{~N}, 21.693097 \mathrm{E}$ \\
\hline
\end{tabular}

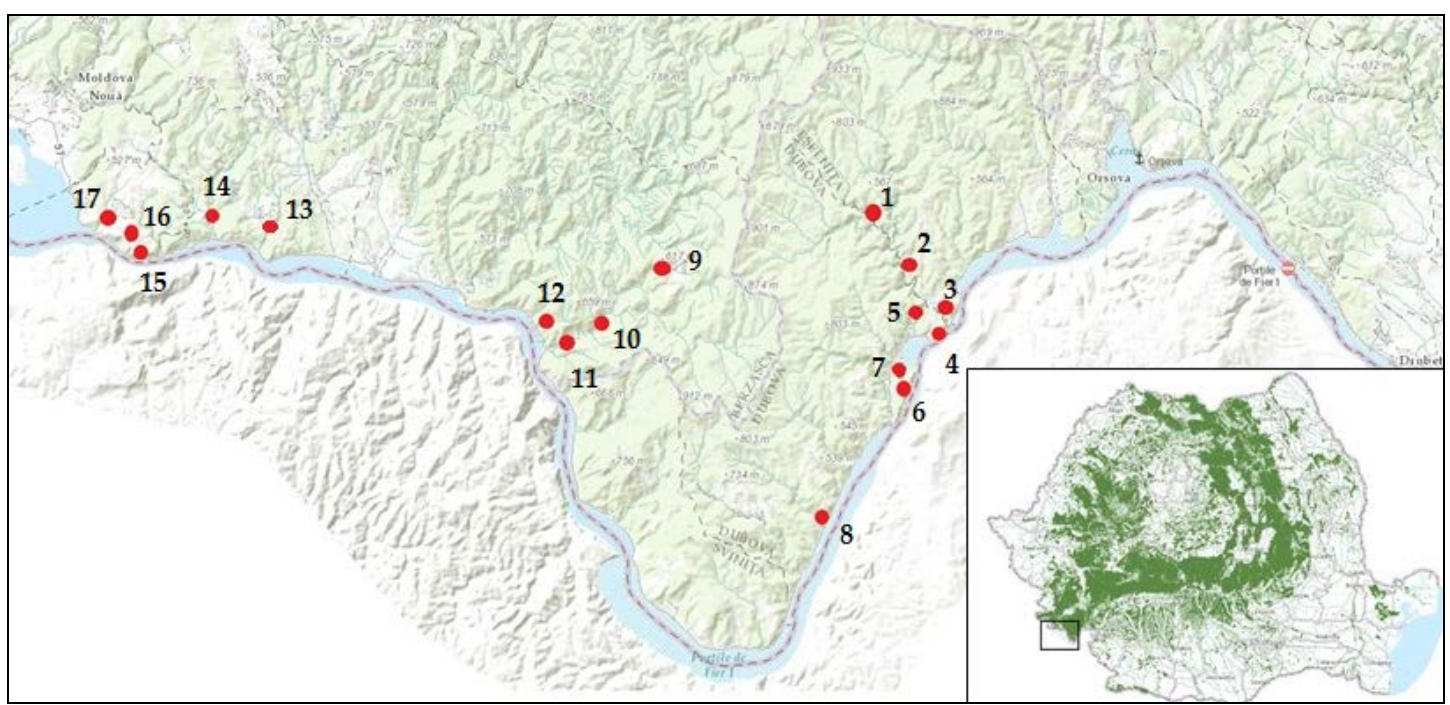

Figure 1: The location of sampling points.

Map source: http://geoportal.ancpi.ro/geoportal/viewer.

The systematic list of land snail species from “Iron Gates” Nature Park

1. Platyla banatica (Rossmässler, 1842): Grossu (1986); present work; in three sampling points in humid forest habitat.

2. Pomatias rivularis (Eichwald, 1829): Grossu (1986), Cameron et al. (2013); present work found in forests on limestone; locally develops large populations.

3. Carychium (Saraphia) tridentatum (Risso, 1826): Cameron et al. (2013); during the sampling in 2014 it was found only on Sirinia Valley.

4. Cochlicopa lubricella (Rossmässler, 1834): Grossu (1987); this work: found in four sampling points, on dry limestone walls or slopes of Ciucaru Mic, Ciucaru Mare, Coronini. 
5. Orcula dolium (Draparnaud, 1801): Grossu (1987), Cameron et al. (2013); present work: a single shell was found on Sirinia Valley; the species known as calciphylous was probably transported from the cliffs by the rainfall.

6. Agardhiella parreysii (Pfeiffer, 1848): Grossu (1987), Cameron et al. (2013); present work: the species was found only on Mraconia Valley.

7. Agardiella grossui (Zilch, 1958): Grossu (1987); not found in the samples taken in 2014.

8. Agardhiella licherdopoli (Grossu, 1986): The species was described by Grossu from the deposits transported by the Danube at Giurgiu, and considered to come from the Danube Gorges. Not found during the current research.

9. Sphyradium doliolum (Bruguière, 1792): Grossu (1987); present work, only found on cliffs from Ciucaru Mic and Ciucaru Mare.

10. Columella edentula (Draparnaud, 1805): Grossu (1987); Cameron et al. (2013); not found during the sampling in 2014.

11. Vallonia costata (Müller, 1774): Grossu (1987); Cameron et al. (2013); present work: large populations on limestone cliffs on Ciucaru Mare and near Coronini.

12. Acanthinula aculeata (Müller, 1774): Grossu (1987); Cameron et al. (2013); present work, only a few shells from Sirinia Valley in forest habitat.

13. Pupilla sterrii (Forster, 1840): Cameron et al. (2013); present work, found on limestone cliffs in Ciucaru Mare and near Coronini.

14. Pyramidula rupestris (Draparnaud, 1801): Cameron et al. (2013); present work, found on limestone cliffs in Ciucaru Mare and near Coronini.

15. Granaria frumentum (Draparnaud, 1801): Grossu (1987); Cameron et al. (2013); present work, the most abundant species on limestone walls, cliffs, and rocks.

16. Chondrina arcadica (Reinhardt, 1881): Grossu (1987); Cameron et al. (2013); present work, also common on limestone cliffs and rocks; usually found together with Granaria frumentum, but less abundant.

17. Truncatellina cylindrica (Férussac, 1807): Grossu (1987); Cameron et al. (2013); present work, found in the leaf litter at the base of limestone cliffs and rocks.

18. Merdigera obscura (Müller, 1774): Cameron et al. (2013); present work, only a few specimens were found in a humid valley near Coronini.

19. Zebrina detrita (Müller, 1774): Not mentioned before by previous authors, but considered common by Grossu (1987); the species is calciphylous and was found in the samples from Ciucaru Mic and near Coronini.

20. Chondrula tridens (Müller, 1774): Not mentioned before, although Grossu (1981) consider it as a common species; present work, on Sirinia Valley.

21. Herilla ziegleri dacica (Pfeiffer, 1848): Grossu (1981); Cameron et al., (2013); present work, common mostly on limestone, mostly in open areas but can occur also in forests if limestone blocks are present.

22. Cochlodina (Cochlodina) laminata laminata (Montagu, 1803): Grossu (1981), Cameron et al. (2013); present work, common species, both on limestone and schist substratum, mostly in the forest.

23. Ruthenica filograna (Rossmässler, 1836): Not mentioned before; present work, only on Sirinia Valley.

24. Clausilia pumila Pfeiffer 1828: Grossu (1981); not found in samples taken in 2014. 
25. Laciniaria plicata (Draparnaud, 1801), Grossu (1981), Cameron et al. (2013); present work, common species, both on limestone and schist substratum, mostly in forest.

26. Alinda biplicata (Montagu, 1803): Grossu (1981); Cameron et al. (2013); present work, one of the most common species, both in open areas and forest mostly the eastern part of the Park (Mraconia, Ciucaru Mare, Ciucaru Mic), highly variable.

27. Bulgarica (Bulgarica) rugicollis pagana (Rossmässler, 1842): Grossu (1981); Cameron et al. (2013); present work, one of the most abundant species, mostly in open areas; highly variable.

28. Bulgarica (Strigilecula) vetusta (Rossmässler, 1836): Grossu (1981); Cameron et al. (2013); present work, locally abundant, on limestone mostly in the forest.

29. Cecilioides (Cecilioides) acicula (Müller, 1774): Not mentioned before. It was found in litter samples taken at the base of limestone cliffs near Coronini.

30. Punctum (Punctum) pygmaeum (Draparnaud, 1801): Grossu (1983); Cameron et al. (2013); present work, in leaf litter samples from Sirinia Valley and near Coronini.

31. Vitrea crystallina (Müller, 1774): Not recorded before, found in leaf litter samples near Coronini.

32. Vitrea contracta (Westerlund, 1871): Not recorded before, found on Sirinia Valley and near Coronini.

33. Carpathica (Ilyrica) langhi (Pfeiffer, 1848): Cameron et al. (2013); present work, found in a single sample on Sirinia Valley.

34. Oxychilus glaber (Rossmässler, 1835): Grossu (1983); Cameron et al. (2013); present work, found both in forests and on limestone rocks. samples.

35. Oxychilus montivagus (Kimakowicz, 1890): Grossu (1983); not found in our

36. Aegopinella epipedostoma Fagot, 1879: Cameron et al. (2013); present work, in the forest from Sirinia Valley and near Coronini.

37. Aegopinella minor (Stabile, 1864): Cameron et al. (2013); present work, the forest on Sirinia Valley.

38. Aegopinella pura (Alder, 1830): Cameron et al. (2013); present work, litter samples from forest near Coronini.

39. Oligolimax annularis (Studer, 1820): Grossu (1983); Cameron et al. (2013); present work, on calcareous substrate, rock rubble habitat on Mraconia Valley, Ciucaru Mic and Ciucaru Mare.

40. Fruticicola fruticum (Müller, 1774): Grossu (1983); Cameron et al. (2013); present work, mostly in forest edges, both on calcareous and silica substrate, not very abundant.

41. Euomphalia strigella Draparnaud, 1801: Grossu (1983); Cameron et al. (2013); present work, present in 12 of the 17 sampling points, mostly in forests of forest edges.

42. Monacha (Monacha) cartusiana (Müller, 1774); not mentioned before, but according to Grossu $(1983)$ is a common species; as for other common species, he did not mentioned all the records; present work, the species was found in samples from bare limestone cliffs and forest edges, near Coronini, in the western part of the park.

43. Xerocampylaea zelebori (Pfeiffer, 1853): Grossu (1983); Cameron et al. (2013); present work, abundant locally, on bare rocks or on herbaceous vegetation.

44. Xerolenta obvia (Menke, 1828): Grossu (1983); present work, locally very abundant; found on bare limestone rocks near Coronini. 
45. Monachoides vicinus Rossmässler, 1842: Grossu (1983); present work, a single record in a forest near Drencova.

46. Monachoides bacescui Grossu 1979: Grossu (1983); Cameron et al. (2013); present work, on both substrates mainly in the forest.

47. Soosia diodonta Férussac, 1832: Grossu (1983), mentioned the species in the western part of the park, near Moldova Nouă; not found in our samples.

48. Cattania trizona (Rossmässler, 1835); Grossu (1983); Cameron et al. (2013); present work, on Mraconia Valley, Ciucaru Mic and Ciucaru Mare.

49. Faustina illyrica (Stabile, 1864): Grossu (1983), consider the species from "Iron Gates" as Campylaea planospira, most probably refers to F. illyrica; present work, the species was found in forests, under the leafs on the ground or on the rocks in Mraconia and Sirinia Valleys, but also on Ciucaru Mic, near Mraconia.

50. Cepaea (Austrotachea) vindobonensis (Pfeiffer, 1828): not specifically mentioned by Grossu (1983) due to its wide distribution; Cameron et al. (2013); present work, a common species, present almost everywhere in the area.

51. Helix (Helix) pomatia Linnaeus, 1758: not specifically mentioned by Grossu (1983), but common; Cameron et al. (2013); present work, mostly in forests, in the eastern part of the area.

\section{CONCLUSIONS}

Land snails are among of the most important invertebrate groups in the "Iron Gates" Nature Park. The generosity of the landscape, combined with the calcareous substrate in the karst areas, allows the presence of large snail population. Although the diversity is not particularly high, some of these species can develop very large populations. The rock crevices or limestone slabs are shelter for many species. Exposed rock can provide vertical surfaces and crevices that are preferred by some snails as Granaria frumentum and Chondrina arcadica. Others, such as the Cattania trizona, are calciphylous and are often observed crawling directly on the vertical surfaces of limestone and rock outcrops in forests - known to be good snail habitats. Among the 44 species found during the sampling in 2014, Cecilioides acicula, Vitrea contracta, Vitrea crystalina and Ruthenica filograna are recorded for the first time in the area. They have a restricted distribution in the park and the small species were only found in leaf litter sampling, so it might be possible that they may have been missed in previous collections. In Regards to the six species that are listed in Grossu, but were not found during the sampling in 2014, most of them are small species, and/or with restricted distribution as Agardiella grossui, Agardhiella licherdopoli, Soosia diodonta and Columella edentula.

One of the main threats for the land snail populations is the mining of mineral resources due to the accessibility of the limestone quarry. The legal and illegal exploitations are disturbing the snail communities related to this type of habitat, which actually represents the most important part of the park's malacofauna. The limited mobility and the continuous landscape change, even after the cessation of exploitation due to the erosion of the limestone walls, makes difficult the decolonization in these areas. 


\section{ACKNOWLEDGEMENTS}

I am grateful to Mr. Szekeres M. who helped me with identifications among Clausiliid species, and the "Iron Gates" Nature Park authorities for the permission to collect in the areas under their management. 


\section{REFERENCES}

1. Cameron R. A. D., Pokryszko B. M., Gheoca V. and Horsak M., 2013 - At the Central European - Balkan transition: forest land snail faunas of the Banat contrasted with those of the Carpathian chain, Acta Biologica Cracoviensia Series Botanica, 55 (Suppl. 1), 21-21. WOS:000325510300007.

2. Culver D. C., Master L. L., Christman M. C. and Hobbs H. H., 2000 - Obligate Cave Fauna of the 48 Contiguous United States, Conservation Biology, 14, 386-401, DOI:10.1046/j.1523-1739. 2000.99026.x.

3. Dvořák L., 2002 - Contribution to the knowledge of snails (Gastropoda) of limestone caves near Moldova Nouă (SW Romania, Banat), Nachrichtenblatt der Ersten Vorarlberger Malakologischen Gesellschaft, 10, 43-47.

4. Gärdenfors U., 1992 - Effects of artificial liming on land snail populations, Journal of Applied Ecology, 29, 50-54.

5. Grossu A. V., 1981 - Gastropoda Romaniae, 3, Ordo Stylommatophora: Suprafamiliile Clausiliacea şi Achatinacea, Bucureşti, 1-248. (in Romanian)

6. Grossu A. V., 1983 - Gastropoda Romaniae, 4, Ordo Stylommatophora, Suprafamiliile: Arionacea, Zonitacea, Ariophantacea şi Helicacea, Edit. Litera, Bucureşti, 1-538. (in Romanian)

7. Grossu A. V., 1986 - Gastropoda Romaniae, 1, Prosobranchia și Opistobranchia, Edit. Litera, Bucureşti, 195-207. (in Romanian)

8. Grossu A. V., 1987 - Gastropoda Romaniae, 2, Subclasa Pulmonata, Ord. Basommatophora şi Ord. Stylommatophora: Suprafam. Succineacea, Cochlicopacea, Pupillacea, Edit. Litera, București, 1-388. (in Romanian)

9. Horsák M., 2006 - Mollusc community patterns and species response curves along a mineral richness gradient: a case study of fens, Journal of Biogeography, 33, 98-107.

10. Kerney M. P. and Cameron R. A. D., 1979 - Field guide to the land snails of the British Isles and northwestern Europe, London, Collins Press, 1-288.

11. Negrea A., 1962 - Contribuție la studiul moluștelor din peșterile din R. P. România (Nota II), Comunicările Academiei R. P. R., Seria Biologie Animală, 12, 1, 37-43, București. (in Romanian)

12. Negrea A., 1963 - Contribuție la studiul moluștelor din peșterile din R. P. România, III, Studii și Cercetări de Biologie, Academia R. P. România, Seria Biologie Animală, XV, 3, 333-342, București. (in Romanian)

13. Negrea A., 1964 - Contribuție la studiul moluștelor din peșterile din R. P. România, Nota IV, Lucrările Institutului de Speologie „Emil Racoviță”, 3, 361-366. (in Romanian)

14. Negrea A., 1966 - Gasteropodele (Mollusca - Gastropoda) din peșterile României, Lucrările Institutului de Speologie „Emil Racoviță”, 5, 125-139. (in Romanian)

15. Nekola J. C., 1999 - Terrestrial gastropod richness of carbonate cliff and associated habitats in the Great Lakes region of North America, Malacologia, 41, 231-252.

16. Welter-Scultes F. W., 2012 - European non-marine molluscs, a guide for species identification, Planet Poster Editions, Göttingen, 1-679.

17. * 1987 - Geografia României III, Carpații și Depresiunea Transilvaniei, Edit. Academiei, București, 647. (in Romanian)

17. **, 1992 - Geografia României, Regiunile pericarpatice, Edit. Academiei, București. (in Romanian) 